DOI:

\title{
The morphological and biochemical investigation of electromagnetic wave effects on urinary bladder in prenatal rats
}

\author{
Prenatal sıçan mesanesi üzerine elektromanyetik dalganın etkilerinin morfolojik ve \\ biyokimyasal olarak incelenmesi \\ Demir KİRAN, Olgu Enis TOK, Ahmet Özer ŞEHİRLİ, Ali Murat GÖKÇE, Feriha ERCAN
}

\begin{abstract}
Objectives: The aim of the study was to investigate the effects of digital cellular system (DCS) 1800-MHz radiation of a common digital mobile phone which has the highest specific absorption rate value of $1.79 \mathrm{~W} / \mathrm{kg}$ on the urinary bladders of male rats.

Materials and Methods: Rats exposed to electromagnetic wave (EMW) emitted by mobile phones on stand-by (Stand-by Fetal Group) or discontinious transmission mode (EMW Fetal group), 2 hours per day, from embryonic day 14 until parturition or until postnatal day 60 (Stand-by Fetal Group). The urinary bladders of the animals in experimental groups were removed at postnatal day 60 and prepared for light and electron microscopical investigation. The barrier function of urothelium was evaluated using zonula occludens 1 and E-cadherin immunohistochemistry and ruthenium red staining for transmission electron microscopy. Oxidative damage was evaluated by biochemical techniques.

Results: EMW wave group showed desquamation of urothelial cells, increased number of mast cells, degeneration of tight junctions and dilatation of intercellular space. Finally, increase in the malondialdehyde and decrease in the glutathione levels were observed in all experimental groups when compared to those in the control group.

Conclusion: Exposure intensity and time length correlate with adverse effects in developing period of the urinary bladder. These changes may lead to urinary bladder inflammatory disorders.

Keywords: Cellular phone, Electromagnetic wave, Urinary bladder, ZO-1, E-cadherin
\end{abstract}

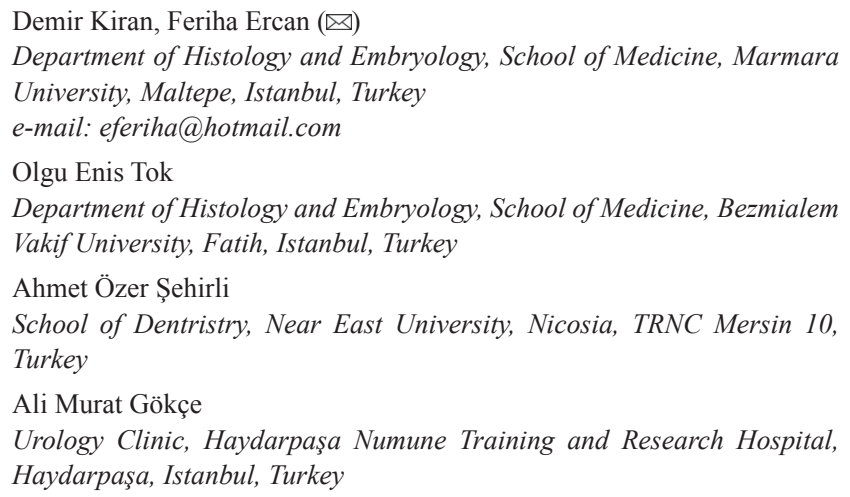

Öz

Amaçlar: Bu çalışmanın amacı, dijital mobil telefonlarından gelen ve en yüksek spesifik absorbsiyon oranı (Specific Absorbtion Rate-SAR) değeri $1,79 \mathrm{~W} / \mathrm{kg}$ olan dijital selüler sistem (DSS) $1800-\mathrm{MHz}$ radyasyonunun erkek siçan mesanesi üzerine etkilerini araştırmaktır.

Gereç ve Yöntem: Siçanlara mobil telefondan stand-by (Stand-by Fetal grup) ya da kesintisiz iletim modunda yayllan elektromagnetik dalga (EMD Fetal grup), günde 2 saat, embriyonik 14. günden doğuma kadar ya da doğumdan sonraki 60 . güne kadar (Stand-by ve EMD grupları) uygulanmıştır. Deney gruplarındaki tüm hayvanların mesaneleri postnatal 60 . günde eter anestezisi altında alınmış ve 1şık ve elektron mikroskopik değerlendirmeler için hazırlanmıştır. Ürotelyumun bariyer fonkisyonu zonula okludens 1 ve E-kaderin immunhistokimyası ve transmisyon elektron mikroskobik inceleme için rutenyum kırmızısı boyaması ile değerlendirilmiştir. Oksidatif hasar biyokimyasal teknikler ile değerlendirilmiştir.

Bulgular: Elektromagnetik dalga grubunda, ürotelyum dökülmeleri, mast hücre sayısında artış, sıkı bağlantılarda hasar ve interselüler alanda genişlemeler gözlenmiştir. Son olarak, kontrol grubu ile kıyaslandığında, tüm gruplarda malondialdehit seviyesinde yükselme ve glutatyon seviyesinde düşüş gözlenmiştir.

Sonuç: Elektromagnetik dalga, maruz kalınan yoğunluk ve süreye paralel olarak, gelişim sürecindeki mesane üzerine olumsuz etki yapmaktadır. $\mathrm{Bu}$ değişiklikler mesanede enflamatuvar hastalıklara sebep olabilir.

Anahtar kelimeler: Cep telefonu, Elektromanyetik dalga, Mesane, ZO-1, E-kaderin

\section{Introduction}

The potential biological effects of electromagnetic waves (EMWs) have become a great concern as well as source of curiosity in the scientific world and in the public. Due to widespread use of mobile phone technology, in addition to wireless local area network (WLAN), bluetooth and wireless digital enhanced cordless telecommunication (DECT) phones, have become one of the most significant sources of EMWs. 
Mobile phones use Time Division Multiple Access (TDMA) in order to allow up to eight users to share the same frequency channel by dividing the signal into different time slots [1]. TDMA causes $217 \mathrm{~Hz}$ ELF frequency because of time slot repetition. During listening phases of active conversation mobile phones use discontinious transmission (DTX) mode with the purpose of reducing the energy consumption. In DTX mode mobile phone bursts control signals once every 26 frame and in this period only control signals and comfort noise are transmitted. DTX mode results in the emission of $2.8 \mathrm{~Hz}$ ELF along with 217 $\mathrm{Hz}$ and $1800 \mathrm{MHz}$ carrier frequency [2].

Electromagnetic waves have thermal and non-thermal effects on biological systems. Thermal effects are local effects associated with heat production like the mechanism of microwave ovens [3]. Because of an international limitation has been brought on specific absorption rate (SAR) which is the quantity used to measure the heating rate, recent studies about mobile phone radiation are focused on non-thermal effects. Many studies conclude that extremely low-frequency and radio frequency EMWs interact with intracellular activity of Na-K ATPase [4] and cytochrome oxidase [5]. Other studies in comparison, have focused on DNA damage and apoptosis caused by EMWs. For example, increased mithocondrial damage of caudal epididymal spermatozoa was documented after exposure to $900 \mathrm{MHz}$ EMW [6]. Also, it has been shown that mobile phones may involve in the formation of free radicals [7]. On the other hand, epidemiological studies about EMW exposure revealed increased risk of childhood leukemia and adult brain cancer [8, 9]. Overall, the World Health Organization (WHO) has classified ELF and radio frequency EMWs in group B as possibly carcinogenic [10].

Recent studies show the importance of EMW's in the pathophisology of genitourinary tract [11]. However, the effects of EMW's on urinary bladder are limited [12]. The incidance of sterile bladder diseases such as interstitial cystitis and overactive bladder syndrome has beeen increasing. Etiology of these diseases is still not clear. The theories for causation of this disorder include the presence of toxic substances in the urine, autoimmunity, infection and psychiatric causes [13]. The morphological criteria for research into interstitial cystitis (IC) have been established as mononuclear inflammation, mucosal hemorrhage, deficiencies in the mucous layer of the bladder, epithelial disruption and increased mast cells in the urothelium [13].

The aim of this study was to investigate the effects of mobile phones with digital cellular system (DSC) 1800
$\mathrm{MHz}$ carrier frequencies and pulse repetition frequencies of $217 \mathrm{~Hz}$ which have the highest SAR values of $1.79 \mathrm{~W} /$ $\mathrm{kg}$ on rat mucosa of the urinary bladder by microscopical and biochemical analysis. In the study, histopathological evaluation, alterations of mucous layer of the bladder, activation of mast cells in the mucosa, distributions of zonula occludens 1 (ZO-1) and E-cadherin in urothelium, permeability of tight juntions were evaluated using light and electron microscopic techniques. Oxidative stress markers malondialdehyde (MDA) and glutatione (GSH) were evaluated using spectrophotometric techniques.

\section{Materials and Methods}

\section{Animals}

The study was performed on Wistar-Albino rats (150$200 \mathrm{~g}$ ) in accordance with institutional guidelines. Mating condition was prepared by putting male and female rats together. Vaginal plaque was accepted as a positive sign of pregnancy (zero day of gestation). Animals were placed in temperature $\left(22 \pm 2{ }^{\circ} \mathrm{C}\right)$ and humidity $(60 \pm 5 \%)$ controlled room in which a $12 / 12 \mathrm{~h}$ light/dark cycle was maintained. All experiments, scheduled between 09:00 and 17:00 h, were performed in accordance with the guidelines for animal research of the National Institutes of Health and were approved by Marmara University Animal Care and Use Committee.(16.02.2011-56.2010.mar).

\section{Experimental groups}

The study was performed in five different groups and six male rats were used in each group. Rats in the control group (a), were not exposed to EMW emitted by mobile phones neither Stand-by nor DTX mode. Animals in the Stand-by Fetal group (b) were exposed to EMW emitted by mobile phones on stand-by mode from embryonic day 14 until parturition and animals in the Stand-by Fetal group (c) were exposed to the same EMW from embryonic day 14 until postnatal day 60. Animals in the EMW Fetal group (d) were exposed to EMW emitted by mobile phones on DTX mode from embryonic day 14 until parturition; and animals in the EMW group (e) were exposed to the same EMW from embryonic day 14 until postnatal day 60. The exposure time was 2 hours per day for all groups. Cell phone devices were fixed in a hanging position $1 \mathrm{~cm}$ above the cages. All of the animals were sacrified at postnatal day 60 under ether anesthesia and urinary bladders were removed. 


\section{Histolopathological evaluation}

For light microscopic investigations, samples from the urinary bladder were placed in $10 \%$ formalin solution and routinely processed after embedding in paraffin. Tissue sections (5 $\mu \mathrm{m})$ were stained with hematoxylin and eosin (H\&E) for histopathological scoring. Periodic acid schiff (PAS) stain was used to observe glycosaminoglycan (GAG) layer. Histopathological damage scoring criteria were desquamation of urothelium and inflammatory cell infiltration. Each of the criteria was evaluated as 0 : normal, 1: mild, 2: moderate, 3 : severe. Maximum score was calculated as 6 .

\section{Mast cell counting}

Paraffin sections after the rehydration procedure stained with $1 \%$ acidified toluidine blue (TB, $\mathrm{pH} 2.5$ ) were used for mast cell counts. Ten areas in each sample were selected randomly and mast cells containing metachromatic degranulated and granulated cells were counted seperately at magnification of 400X. The area of $0.0754 \mathrm{~mm}^{2}$ was selected in each region and were surveyed for mast cells and the mast cell density then expressed as mast cell number per unit area.

\section{ZO-1 and E-cadherin immunohistochemistry}

Approximately, $3 \mu \mathrm{m}$-thick paraffine sections were incubated overnight at $56^{\circ} \mathrm{C}$. After deparaffinization and rehydration, the sections were incubated in a solution of $3 \% \mathrm{H}_{2} \mathrm{O}_{2}$ for 5 min to inhibit endogenous peroxidase activity. Then, the sections were washed with PBS and treated with protease $\left(1 \mathrm{mg} / \mathrm{ml}\right.$, Sigma-Aldrich, Missouri, United States) at $37^{\circ} \mathrm{C}$ for 10 min or microwaved with citrate buffer $\mathrm{pH} 6.1$ for 20 min for antigen retrieval, sections were incubated with $10 \%$ non-immun goat blocking solution for 10 min (reagent A, Histostain plus 3rd generation IHC detection kit, Invitrogen, California, United States). Following incubation with primary anti- ZO-1 (1:100 dilution, Invitrogen) or primary anti- E-cadherin (1:300 dilution, Abcam, Cambridge, United Kingdom) antibody developed in rabbit overnight at $4^{\circ} \mathrm{C}$. After washing in PBS and the sections were incubated with biotinylated secondary antibody (reagent B, Histostain plus 3 rd generation IHC detection kit) for $10 \mathrm{~min}$. The sections were washed with PBS, incubated with AEC (for ZO-1) or $\mathrm{DAB}$ (for E-cadherin) for $15 \mathrm{~min}$ to visualize immunostaining and finally counterstained with Mayer's hematoxylin (Zymed Laboratories, California, United States). Control samples were processed in the same manner except that the primary antibodies were omitted. An observer blind to the experimental groups evaluated the staining intensity semi-quantitatively. Staining intensity was graded as none $(-)$, less $(+/-)$, weak $(+)$, dense $(++)$ and intense $(+++)$.

All of the stained sections were observed and photographed with a digital camera (Olympus C-5060, Tokyo, Japan) attached to a photomicroscope (Olympus BX51).

\section{Electron microscopic preparation}

For scanning electron microscopic (SEM) investigations the samples were fixed in $4 \%$ phosphate buffered glutaraldehyde $(0.13 \mathrm{M}$ and $\mathrm{pH} 7.4)$ for $4 \mathrm{~h}$, postfixed with $1 \% \mathrm{OsO}_{4}$ for 1 $\mathrm{h}$, dehydrated through a graded alcohol series, put into amyl acetate, dried with liquid $\mathrm{CO}_{2}$ under pressure with a critical point dryer (Bio-Rad E 3000, Hertfordshire, UK) and coated with gold particles (Bio-Rad SC502). These samples were observed using a Jeol 1200 JSM (JEOL, Tokyo, Japan) SEM.

For transmission electron microscopic (TEM) investigations the specimens were fixed in $4 \%$ phosphate buffered gluteraldehyde ( $0.13 \mathrm{M}$ and $\mathrm{pH} 7.4)$ for $4 \mathrm{~h}$, postfixed with $1 \% \mathrm{OsO}_{4}$ for $1 \mathrm{~h}$, dehydrated in a graded alcohol series and embedded in epon 812 . In order to observe the premeability of tight junction at the TEM level, the specimens were then stained en bloc with ruthenium red (RR) and postfixed with $\mathrm{OsO}_{4}$ (1:4 ratio). These samples were stained en bloc within a ratio of $1 / 5$ stock RR solution and $2 \%$ uranyl acetate and prepared for TEM investigations. Ultrathin sections were stained with uranyl acetate and lead citrate and observed at the Jeol 1200 EX II transmission electron microscope at 80 $\mathrm{kV}$ accelerating voltage and photographed with side mounted digital camera (Olympus Morada Soft Imaging System).

\section{Malondialdehyde and glutathione assays}

Malondyaldehyde and GSH levels were evaluated for the estimation of tissue oxidative damage. The samples obtained from urinary bladder were homogenized in ice cold $150 \mathrm{mmol}$ $\mathrm{KCl}$ for the determination of MDA and GSH levels. For MDA determination, the colored complex formed by the reaction of MDA with thiobarbituric acid was quantified spectrophotometrically. GSH was determined by the spectrophotometric method using the Ellman's reagent. The results were expressed as MDA nmol/g tissue and GSH $\mu \mathrm{mol} / \mathrm{g}$ tissue.

\section{Statistical analysis}

Statistical analysis of all data was carried out using Graph Pad Prism 3.0 (Graph Pad Software, San Diego, CA, USA). All data were expressed as mean \pm S.D. The results of histopathological scoring, mast cell counting, MDA and GSH levels were compared using an analysis of variance 
(ANOVA) followed by Tukey's multiple comparison tests. Values of $P<0.05$ were regarded as significant.

\section{Results}

\section{Histopathological evaluation}

Normal mucosal morphology with regular overlying urothelium and GAG layer was observed in the control group. Quite regular urinary bladder morphology was observed in Stand-by Fetal and EMW Fetal group. However, urothelial thinning and local desquamation with irregular GAG leyer were observed in Stand-by group and severe urothelial desquamation with the local loss of GAG layer and inflammatory cell infiltration were evident in the EMW group (Fig. 1A-E and $1 \mathrm{~A}_{1}-\mathrm{E}_{1}$ ).
Histopathological score was not significant in Stand-by Fetal and EMW Fetal groups, but, significantly higher in Stand-by $(P<0.05)$ and EMW $(P<0.001)$ groups when compared to control group (Fig. 2A).

\section{ZO-1 and E-cadherin immunohistochemistry}

Reddish-coloured ZO-1 immunoreactivity (ir) was observed in the lateral surface of apical urothelial cells in the control group. ZO-1 localization and density was similar to control group in the Stand-by Fetal and EMW Fetal groups. ZO-1 ir was mildly decreased in the Stand-by group, but severely decreased in the EMW group (Fig. 3AE, Table 1).
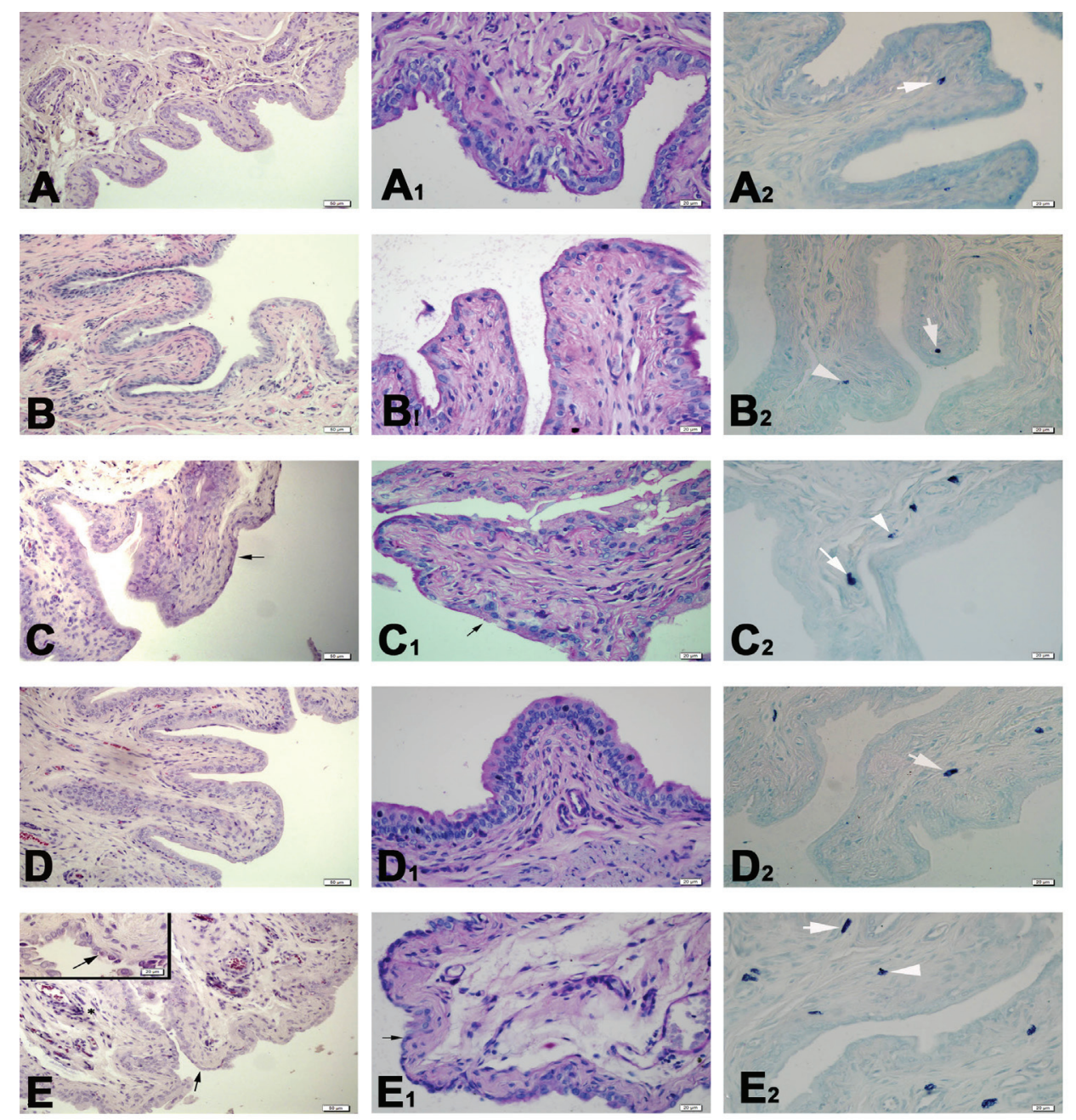

Figure 1. Representative histological micrographs of the experimental groups. Regular mucosa and urothelium (A, B, D) with regular GAG layer $\left(A_{1} B_{1} D_{1}\right)$, granulated (arrow) and degranulated (arrowhead) mast cells $\left(A_{2} B_{2} D_{2}\right)$ in lamina propria in Control, Stand-by Fetal, and EMW Fetal groups, respectively. Localised thinning of urothelial layer (arrow, C) and disorganised GAG layer (arrow, $\mathrm{C}_{1}$ ), a few granulated (arrow) and degranulated (arrowhead) mast cells $\left(\mathrm{C}_{2}\right)$ in Stand-by group. Thining and localised desquamation of urothelial layer (arrow, E), inflammatory cell infiltration (asterisk, E) in lamina propria, irregular GAG layer (arrow, $\mathrm{E}_{1}$ ), and increased number of granulated (arrow) and degranulated (arrowhead) mast cels $\left(\mathrm{E}_{2}\right)$ in EMW group. A-E: H\&E staining, A1-E1: PAS staining, A2-E2: Toluidine blue staining 
A

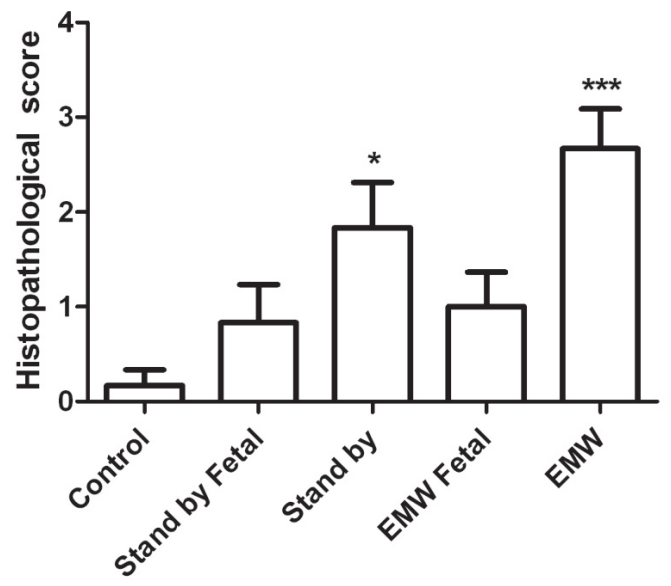

B

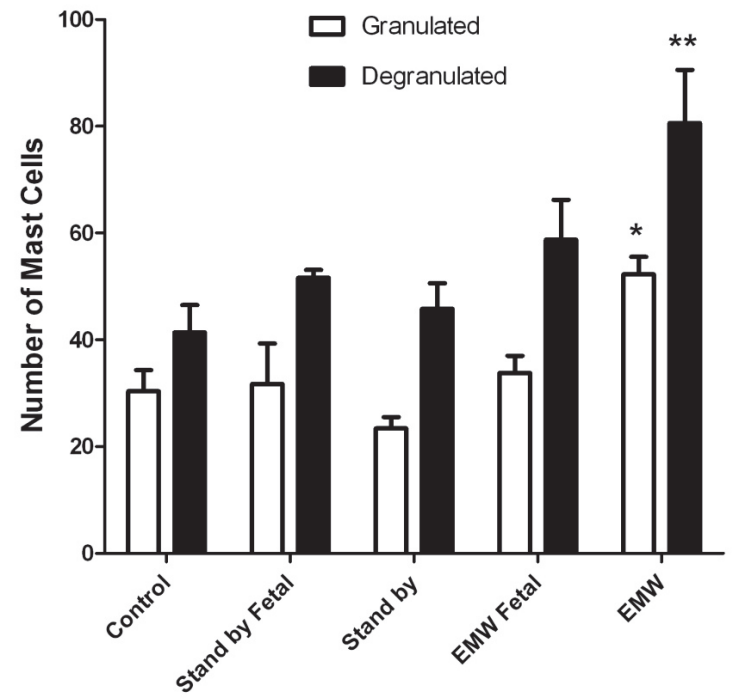

Figure 2. Semiquantitative histopathological scoring (A) and granulated and degranulated mast cells (B) in Control, Standby Fetal, Stand-by, EMW Fetal and EMW groups. * $P<0.05$; ** $P<0.01$; *** $P<0.001$ vs Control group.

\section{Mast cell count}

The increase of granulated mast cell number was not significant in Stand-by Fetal, Stand-by and EMW Fetal groups compared to control group. There was an increase in both granulated and degranulated mast cell number in the EMW group $(P<0.05)$ and there was an increase only in degranulated mast cell number in EMW Fetal group $(P<0.05)$ compared to the control group (Fig. $1 \mathrm{~A}_{2}-\mathrm{E}_{2}$ and Fig. 2B).

E-cadherin immunostaining was localized in a linear fashion at the basolateral site of the urothelial cells in the control group. E-cadherin ir was similar to the control group in Stand-by Fetal, Stand-by and EMW Fetal groups. E-cadherin ir was decreased in EMW group (Fig. $3 \mathrm{~A}_{1}-\mathrm{E}_{1}$, Table I).

\section{Ultrastructural evaluation}

Luminal surface of the urinary bladder with urothelial cells was regular in the Control, Stand-by Fetal, Stand-by and EMW Fetal groups at SEM level. Desquamation of apical urothelial cells was observed in the Stand-by group and the local ulcerated area was present in the EMW group (Fig. 4A-E).

TEM observations showed impermeable tight junctions for RR dye in the control group. RR leakage was present in

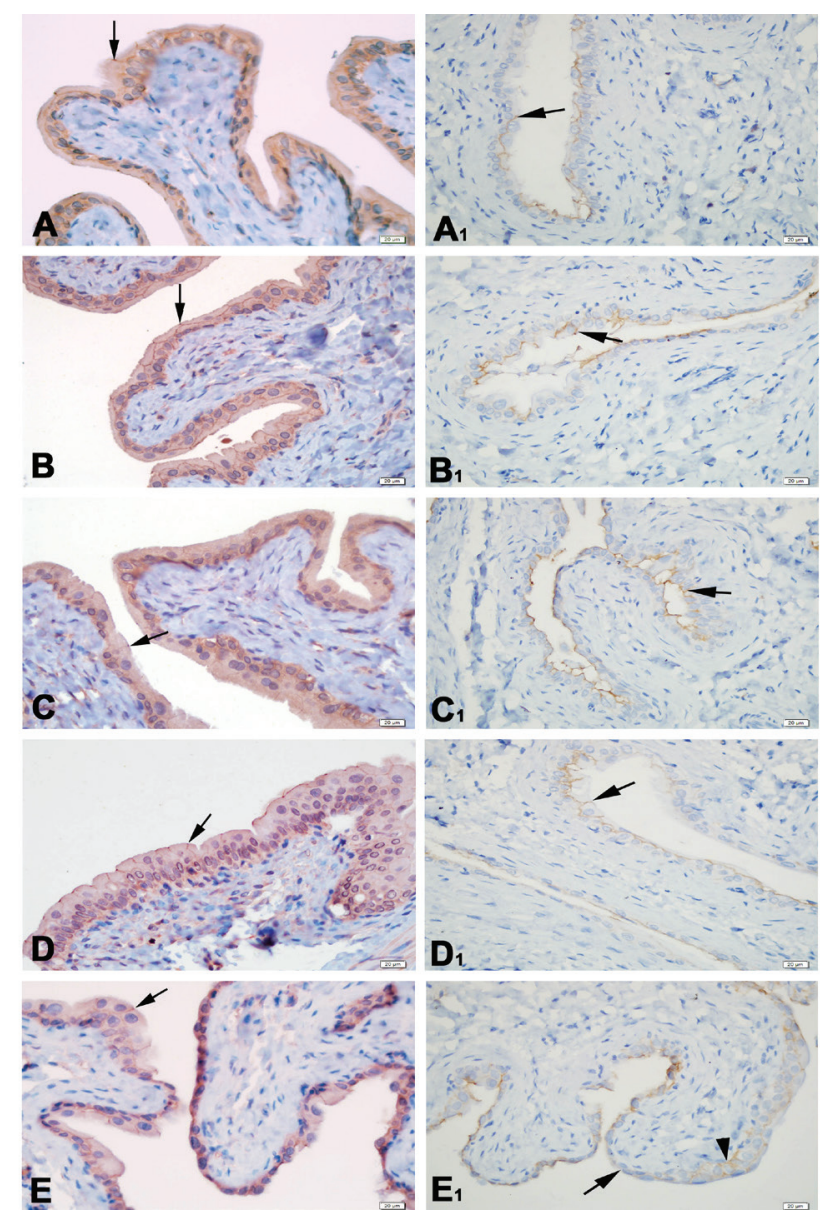

Figure 3. ZO-1 (A-E) and E-cadherin (A1-E1) immunoreactivity (ir) in experimental groups. Similar ZO-1-ir (arrow, A-E) and E-cadherin-ir (arrow, A1-E1) in Control (A, A1), Stand-by Fetal (B, B1) and EMW-Fetal (D, D1) groups, respectively. Dense ZO1-ir (arrow, C) and E-cadherin-ir (arrow, C1) in Stand-by group, and weak ZO-1-ir (arrow, E) and weak (arrow) and disorganised (arrowhead) E-cadherin-ir (E1) in EMW group. 
Table I. Semiquantitative assessment of the intensity of ZO-1 and E-cadherin immunoreactivity in Control, Stand-by Fetal, Stand-by, EMW Fetal and EMW groups, (+++, intense; ++, dense; +, weak; +/-, least; -, none).

\begin{tabular}{|l|l|l|l|l|l|}
\hline & Control & Stand-by Fetal & Stand-by & EMW Fetal & EMW \\
\hline ZO-1 & +++ & +++ & ++ & +++ & + \\
\hline E-cadherin & +++ & +++ & +++ & +++ & ++ \\
\hline
\end{tabular}
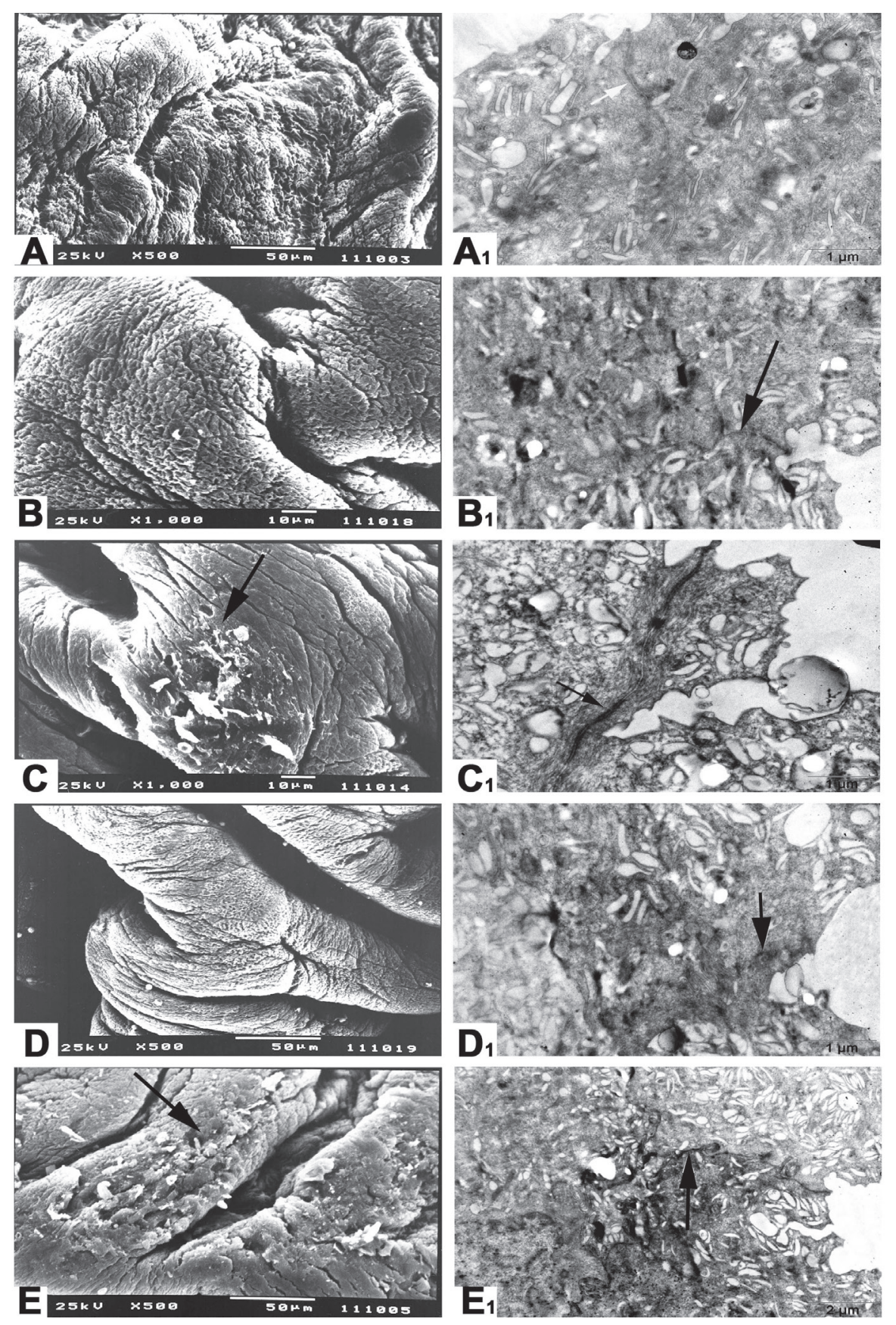

Figure 4. Representative ultrastructural micrographs of the experimental groups. Regular luminal surface of the urinary bladder with urothelial cells in Control (A), Stand-by Fetal (B), Stand-by (C) and EMW Fetal (D) groups at SEM level. Desquamation of apical urothelial cells (arrow, C) in Stand-by group and local ulcerated area (arrow, E) in EMW group at SEM level. Impermeable tight junction (arrow, $A_{1}$ ) in Control group at TEM level. Some ruthenium red (RR) stained intercellular regions (arrow) in Stand-by Fetal ( $B_{1}$ ) and EMW Fetal $\left(D_{1}\right)$ groups, moderate RR penetration in intercellular spaces (arrow, $C_{1}$ ) in Stand-by group and RR penetration in most regions of intercellular spaces (arrow, $\mathrm{E}_{1}$ ) in EMW group at TEM level. 
some intercellular region of Stand-by Fetal and EMW Fetal groups. RR penetration into the intercellular region was moderate in Stand-by group. RR penetration was observed in most regions of the intercellular spaces in EMW group (Fig. 4A $-\mathrm{E}_{1}$ ).

\section{Biochemical evaluation of MDA and GSH levels}

The concentration of MDA level was significantly increased in all groups except Stand-by Fetal group when compared to control group. The decrease in urinary bladder concentration of GSH level was significant in all groups compared to the control group (Fig. 5A, B).

A

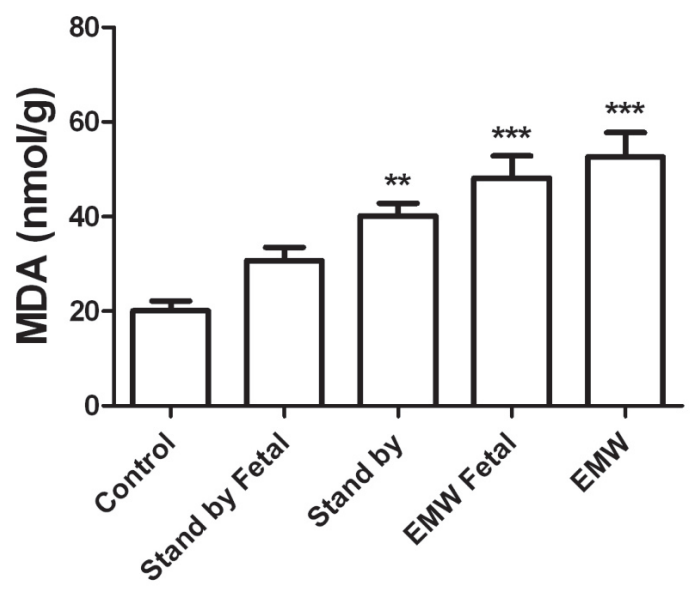

B

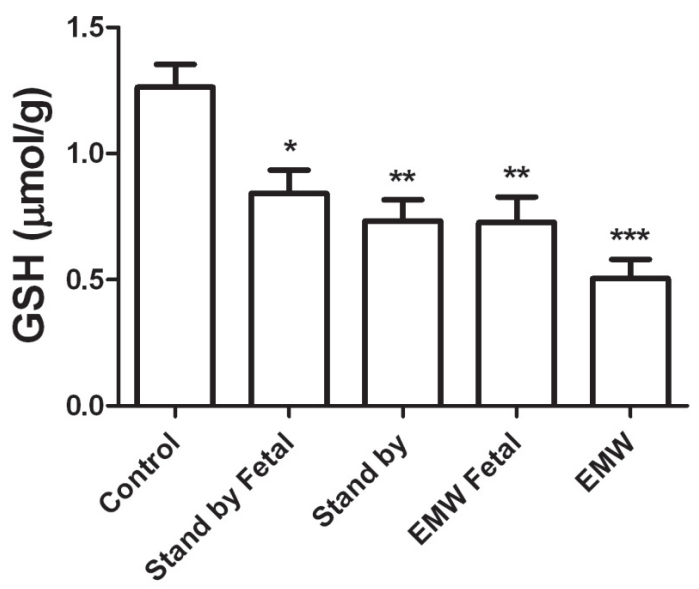

Figure 5. MDA (A) and GSH (B) concentrations in Control, Stand-by Fetal, Stand-by, EMW Fetal and EMW groups. $* P<0.05$; ** $P<0.01$; *** $P<0.001$ vs Control group.

\section{Discussion}

The present study reveals that long period EMW exposure starting from the prenatal life until adulthood causes alteration of urothelial impermeability and urothelial damage, mast cell activation and increase in the lipid peroxidation. Stand-by mode of the EMW exposure also causes mild urinary bladder alteration.

The urothelium plays an important role as a barrier between urine and the underlying bladder. Urinary bladder surface GAGs consist of repeating disaccaride units which bind to proteoglycan core proteins and are critical components of this barrier formed by the urothelium [14]. Alterations in the expression of proteoglycan core proteins biglycan, decorin, perlecan and syndecan-1 can affect the actions of cytokines which mediate bladder sensation and increase the permeability of urothelium [15]. Alterations in the synthesis of proteoglycans not only affect the barrier function but also deteriorate the normal physiology of urothelial cells. Defects in the GAG layer as detected in this study may contribute pathophysiology of IC. GAG replenishment therapies, which have proven to be an effective treatment for IC, also strengthen this theory [16].

The EMW and EMW Fetal groups presented higher significant results in terms of increased mast cell number and MDA levels with decreased GSH levels when compared to other groups that indicated inflammation and oxidative damage. The oxidative damage can occur due to mast cells [17] which are capable of generating reactive oxygen species (ROS). It can also occur as a result of the direct activation of plasma-membrane-associated NADH oxidase by electromagnetic fields generated by mobile phones. But because the mast cells have expanded life spans in mucosal tissue and the consistent association between the mast cell numbers and oxidation marker levels within the experimental groups puts forward the first hypothesis. It can be said that the mast cells at some point contribute to the pathology of inflammation instead of playing a beneficial role in host defense. Also increased number of activated mast cells have been described in inflammatory urinary bladder conditions like IC [18].

In previous studies urinary bladder [12] and kidney damages [19] were observed on mature rats after exposing EMW for 20 days. In an another study EMW exposure was applied to the rats in prenatal period and observed harmful effect on the kidney development [20]. In this study we also observed the degenerative effects of EMW exposure in 
stand-by mode and adverse effects in developing period of urinary bladder.

Several molecules have been shown to regulate tight junction (TJ) dynamics, including, protein kinase C (PKC), G-protein and intracellular and extracellular $\mathrm{Ca}^{+2}$ [21]. Blood brain barrier can be disrupted by EMWs accompanied by alterations in the expression and distribution of ZO-1 protein. PKC plays an important role in the regulation of Sertoli cell tight junctions [22] and it has been shown that EMWs exposure could increase the permeability of blood testis barrier in the mouse seminiferous tubules [23]. EMWs can affect plasma membrane $\mathrm{Ca}^{+2}$ channels and disrupt $\mathrm{Ca}^{+2}$ homeostasis by altering extra- and intracellular $\mathrm{Ca}^{+2}$ concentration [24]. Yet the mechanisms that regulate these events are essentially not known, decreased expression of ZO-1 in urotelium and diffusion of RR throughout the intercelluler space in this study showed that mobile phone EMWs can damage the intercellular junctional structures of rat urothelium. It is well known that abnormal E-cadherin and ZO-1 expression as well as increase in infiltration of mast cells in the urothelium are associated with IC/painful bladder syndrome (IC/PBS) [25, 26].

In conclusion, exposure to EMW beginning from fetal period until postnatal period caused irregularity of GAG layer and desquamation of urothelium, inflammatory cell infiltration and activation of mast cells, alteration in tight junction protein expression such as ZO-1 and E-cadherin, changes in the permeability of urothelium and increase of lipid peroxidation. Additionally, EMWs in stand-by mode may cause urothelial damage and change the function of urothelial barrier. However, these morphological and biochemical results should be supported by bladder contractility studies. Effects of EMWs are related with the intensity, exposure time length and the distance to the source and it might lead to the development of the chronic inflammatory urinary bladder diseases.

Acknowledgement: The study was supported by Marmara University Research Fund (SAG-CTUP-040712-0267). The authors wish to thank Dr. Dilek Akakın for her helpful and detailed criticism and comments for the manuscript.

Decleration of interest: The authors report no declarations of interest.

\section{References}

1. Kundi M. Mobile phone use and cancer. Occup Environ Med 2004; 61:560-70. doi: 10.1136/oem.2003.007724

2. Czyz J, Guan K, Zeng Q, et al. High frequency electromagnetic fields (GSM signals) affect gene expression levels in tumor suppressor p53-deficient embryonic stem cells. Bioelectromagnetics 2004; 25:296-307. doi: 10.1002/ bem.10199

3. Deepinder F, Makker K, Agarwal, A. Cell phones and male infertility: dissecting the relationship. Reprod Biomed Online 2007;15:266-70. doi: http://dx.doi.org/10.1016/S14726483(10)60338-0

4. Blank, M. Do electromagnetic fields interact with electrons in the Na, K-ATPase? Bioelectromagnetics 2005;26:677-83. doi: 10.1002/bem.20167

5. Blank M, Soo L. Optimal frequencies for magnetic acceleration of cytochrome oxidase and $\mathrm{Na}, \mathrm{K}$-ATPase reactions. Bioelectrochemistry 2001;53:171-4. doi: 10.1016/ S0302-4598(00)00128-8

6. Aitken RJ, Bennetts LE, Sawyer D, et al. Impact of radio frequency electromagnetic radiation on DNA integrity in the male germline. Int $\mathrm{J}$ Androl 2005; 28:171-9. doi: 10.1111/j.1365-2605.2005.00531.x

7. Yakymenko I, Tsybulin O, Sidorik E, et al. Oxidative mechanisms of biological activity of low-intensity radiofrequency radiation. Electromagn Biol Med 2015; 7:117. doi: 10.3109/15368378.2015.1043557

8. Ahlbom A, Day N, Feychting M, et al. A pooled analysis of magnetic fields and childhood leukaemia. Br J Cancer 2000; 83:692-8. doi:10.1054/bjoc.2000.1376

9. Hardell L, Carlberg M, Soderqvist F,et al. Long-term use of cellular phones and brain tumours: increased risk associated with use for $>$ or $=10$ years. Occup Environ Med 2007; 64:626-32. doi: 10.1136/oem.2006.029751

10. IARC Working Group on the Evaluation of Carcinogenic Risks to Humans. Non-ionizing radition, Part 2: Radiofrequency electromagnetic fields. IARC Monogr Eval Carcinog Risks Hum 2013; 102(Pt 2):1-460.

11. Oktem F, Ozguner F, Mollaoglu H, et al. Oxidative damage in the kidney induced by $900-\mathrm{MHz}-\mathrm{emitted}$ mobile phone: protection by melatonin. Arch Med Res 2005; 36:350-5. doi: 10.1016/j.arcmed.2005.03.021

12. Koca O, Gokce AM, Akyuz M, et al. A new problem in inflammatory bladder diseases: use of mobile phones! Int Braz J Urol 2014;. 40:520-25. doi: 10.1590/S1677-5538. IBJU.2014.04.11.

13. Gillenwater, JY, Wein AJ. Summary of the National Institute of Arthritis, Diabetes, Digestive and Kidney Diseases Workshop on interstitial cystitis, National Institutes of Health. J Urol 1988;.140:203-6.

14. Lewis SA. Everything you wanted to know about the bladder epithelium but were afraid to ask. Am J Physiol Renal Physiol 2000; 278:867-74.

15. Hauser PJ, Dozmorov MG, Bane BL, et al. Abnormal expression of differentiation related proteins and proteoglycan core proteins in the urothelium of patients with 
interstitial cystitis. J Urol 2008; 179:764-9. doi:10.1016/j. juro.2007.09.022.

16. Iavazzo $\mathrm{C}$, Athanasiou $\mathrm{S}$, Pitsouni E, et al. Hyaluronic acid: an effective alternative treatment of interstitial cystitis, recurrent urinary tract infections, and hemorrhagic cystitis? Eur Urol 2007; 51:1534-40. doi:10.1016/j.eururo.2007.03.020.

17. Brooks AC, Whelan CJ, Purcell WM. Reactive oxygen species generation and histamine release by activated mast cells: modulation by nitric oxide synthase inhibition. Br J Pharmacol 1999; 128:585-90. doi:10.1038/sj.bjp.0702838.

18. Sant GR, Kempuraj D, Marchand JE, et al. The mast cell in interstitial cystitis: role in pathophysiology and pathogenesis. Urology 2007; 69 (4 Suppl):34-40. doi:10.1016/j. urology.2006.08.1109.

19. Koca O, Gökçe AM, Öztürk MI, et al. Effects of intensive cell phone (Philips Genic 900) use on the rat kidney tissue. Urol J 2013;10:886-91. doi:10.1016/S1569-9056(13)603097.

20. Bedir R, Tumkaya L, Şehitoğlu I, et al. The effect of exposure of rats during prenatal period to radiation spreading from mobile phones on renal development. Ren Fail 2015; 37:3059. doi:10.3109/0886022X.2014.985995.

21. Qiu LB, Ding GR, Li KC, et al. The role of protein kinase $\mathrm{C}$ in the opening of blood-brain barrier induced by electromagnetic pulse. Toxicology 2010; 273:29-34. doi:10.1016/j.tox.2010.04.013.

22. Lui WY, Cheng CY. Regulation of cell junction dynamics by cytokines in the testis: a molecular and biochemical perspective. Cytokine Growth Factor Rev 2007; 18:299-311. doi: 10.1016/j.cytogfr.2007.04.009.

23. Wang XW, Ding GR, Shi CH, et al. Effect of electromagnetic pulse exposure on permeability of blood-testicle barrier in mice. Biomed Environ Sci 2008;21:218-21. doi:10.1016/ S0895-3988(08)60032-X.

24. Blackman CF, Elder JA, Weil CM, et al. Induction of calciumion efflux from brain tissue by radio-frequency radiation: Effects of modulation frequency and field strength. Radio Science 1979; 14:93-8. doi:10.1029/RS014i06Sp00093.

25. Shie JH, Kuo HC. Higher levels of cell apoptosis and abnormal E-cadherin expression in the urothelium are associated with inflammation in patients with interstitial cystitis/painful bladder syndrome. BJU Int 2011;108(2 Pt 2):E136-41. doi:10.1111/j.1464-410X.2010.09911.x.

26. Liu HT, Shie JH, Chen SH, et al. Differences in mast cell infiltration, E-cadherin, and zonula occludens-1 expression between patients with overactive bladder and interstitial cystitis/bladder pain syndrome. Urology 2012;80:225.e13. doi:10.1016/j.urology.2012.01.047. 